\title{
Pengaruh Dana Perimbangan dan Investasi terhadap Pertumbuhan Ekonomi di Provinsi Jambi
}

\author{
Atmini Lara Santi ${ }^{1^{*}}$, Hardiani ${ }^{2}$, Rosmeli ${ }^{3}$ \\ ${ }^{1,2,3)}$ Fakultas Ekonomi dan Bisnis, Universitas Jambi, Jl. Raya Jambi - Muara Bulian KM. 15, Muaro \\ Jambi, Jambi \\ Diterima: 18-07-2021 \\ Direvisi: $30-07-2021$ \\ Disetujui: 31-07-2021 \\ Dipublikasi: 03-08-2021
}

\begin{abstract}
This study aims to analyze the effect of fiscal balance funding and investment on economic growth in Jambi Province. The data used is time-series data from 2002-2018. The data is sourced from the Central Statistics Agency of Jambi Province and the Directorate General of Fiscal Balance of the Ministry of Finance of the Republic of Indonesia. Data were analyzed by multiple regression analysis. The study results show that, either simultaneously or partially, Profit Sharing Funds, General Allocation Funds, Special Allocation Funds, Foreign Investments, and Domestic Investments have a significant influence on economic growth in Jambi Province.
\end{abstract}

Keywords: economic growth, fiscal balance, investment

\begin{abstract}
Abstrak
Penelitian ini bertujuan untuk menganalisis pengaruh dana perimbangan dan investasi terhadap pertumbuhan ekonomi di Provinsi Jambi. Data yang digunakan adalah data time series tahun 20022018. Data bersumber dari Badan Pusat Statistik (BPS) Provinsi Jambi dan Direktorat Jenderal Perimbangan Keuangan (DJPK) Kementerian Keuangan Republik Indonesia. Data dianalisis dengan alat analisis regresi berganda. Hasil penelitian menunjukkan bahwa baik secara simultan maupun parsial, Dana Bagi Hasil, Dana Alokasi Umum, Dana Alokasi Khusus, Penanaman Modal Asing, dan Penanaman Modal Dalam Negeri memiliki pengaruh yang signifikan terhadap pertumbuhan ekonomi di Provinsi Jambi.
\end{abstract}

Kata kunci: pertumbuhan ekonomi, dana perimbangan, investasi

\section{Pendahuluan}

Pertumbuhan ekonomi merupakan sebuah ukuran atas perkembangan atau kemajuan perekonomian suatu negara karena adanya keterkaitan yang sangat erat dengan kegiatan ekonomi masyarakat terutama dalam hal peningkatan produksi barang dan jasa. Peningkatan produksi inilah yang diharapkan mampu untuk mendorong kesejahteraan masyarakat. Pertumbuhan ekonomi dalam sistem pemerintahan daerah biasanya diartikan dengan meningkatnya produksi barang yang diukur dengan PDRB (Produk Domestik Regional Bruto). PDRB juga bisa didefinisikan sebagai nilai tambah bruto seluruh barang dan jasa yang tercipta atau dihasilkan di wilayah domestik suatu negara yang timbul akibat berbagai aktivitas ekonomi dalam periode tertentu (Pangiuk, 2017).

Pertumbuhan ekonomi adalah suatu proses perubahan keadaan perekonomian suatu negara secara berkelanjutan menuju ke arah yang lebih baik dalam kurun waktu tertentu. Pertumbuhan ekonomi juga bisa disebut sebagai proses meningkatnya jumlah produksi suatu

\footnotetext{
${ }^{*}$ Penulis korespondensi

Email: atminials3897@gmail.com
} 
perekonomian yang ditunjukkan dari meningkatnya pendapatan nasional. Menurut Todaro (dalam Rofii \& Ardyan, 2017), ada tiga faktor atau elemen utama yang mempengaruhi pertumbuhan ekonomi, yakni akumulasi modal (capital accumulation), pertumbuhan penduduk (population growth), dan kemajuan teknologi (technological advances).

Berdasarkan data Badan Pusat Statistik (BPS), pertumbuhan ekonomi Provinsi Jambi sepanjang tahun 2014 mengalami fluktuasi. Pada tahun 2014, terjadi peningkatan dari 7,07 persen menjadi 7,76 persen. Sementara itu, pertumbuhan ekonomi Provinsi Jambi pada tahun 2015 mengalami penurunan dari tahun sebelumnya, yaitu 4,21 persen. Pertumbuhan ekonomi di Provinsi Jambi mulai mengalami peningkatan di tahun 2016, yakni 4,37 persen. Pada tahun 2017 dan 2018, peningkatan juga terjadi menjadi masing-masing 4,64 persen dan 4,71 persen. Seperti tahun-tahun sebelumnya, struktur ekonomi Provinsi Jambi masih dikuasai oleh sektor pertanian, dan kehutanan dan perikanan yang memberikan kontribusi besar terhadap PDRB Provinsi Jambi. Sektor lainnya yang dominan adalah sektor pertambangan dan penggalian. Di sisi pengeluaran, PDRB Provinsi Jambi banyak digunakan untuk pengeluaran ekspor.

Dana perimbangan merupakan dana yang bersumber dari APBN (Anggaran Pendapatan dan Belanja Negara) yang dialokasikan kepada daerah untuk mendanai kebutuhan daerah dalam rangka pelaksanaan desentralisasi. Dana perimbangan ini bertujuan untuk mengurangi kesenjangan fiskal antara pemerintah pusat dan pemerintah daerah (Sidik dalam Taaha, dkk., 2010). Dana perimbangan diharapkan dapat meningkatkan efisiensi pengeluaran pemerintah dengan menyerahkan sebagian hak kepada daerah untuk dapat mengelola keuangan agar dapat mengurangi ketimpangan dalam hal keuangan. Dana perimbangan terdiri dari Dana Bagi Hasil, Dana Alokasi Umum, dan Dana Alokasi Khusus. Dana inilah yang akan digunakan oleh pemerintah daerah untuk biaya pengeluaran.

Dana Bagi Hasil adalah dana yang berasal dari APBN dan dialokasikan ke daerah berdasarkan jumlah persentase tertentu. Berdasarkan data yang diperoleh dari DJPK (Direktorat Jenderal Perimbangan Keuangan), Dana Bagi Hasil selama lima tahun terakhir mengalami fluktuasi. Selama periode tahun 2014-2015, pertumbuhan terendah terjadi pada tahun 2015 dengan tingkat pertumbuhan negatif sekitar -34,71 persen dan pertumbuhan Dana Bagi Hasil tertinggi terjadi pada tahun 2017 dengan tingkat pertumbuhan sebesar 32,51 persen. Tingkat pertumbuhan pada tahun 2014, 2016, dan secara berturut-turut, yaitu 29,29 persen, -10,16 persen, dan -2,91 persen (Direktorat Jenderal Perimbangan Keuangan Kemenkeu [DJPK Kemenkeu], 2019).

Dana Alokasi Umum adalah dana APBN yang bertujuan agar terciptanya pemerataan kemampuan keuangan. Dalam lima tahun terakhir (2014-2018), pertumbuhan Dana Alokasi Umum bervariasi. Pertumbuhan terendah terjadi pada tahun 2016, yaitu $-1,16$ persen, dan pertumbuhan tertinggi terjadi pada tahun 2017, yaitu 40,15 persen. Tingkat pertumbuhan pada tahun 2014, 2015, dan 2018 secara berturut-turut, yaitu 29,51 persen, 5,78 persen, dan 0,1 persen (DJPK Kemenkeu, 2019)

Dana Alokasi Khusus merupakan dana APBN yang dialokasikan untuk membiayai kebutuhan secara khusus. Pada periode 2014-2018, pertumbuhan Dana Alokasi Khusus mengalami fluktuasi. Pada tahun 2018, Dana Alokasi Khusus mengalami tingkat pertumbuhan rendah, yaitu sekitar 0,5 persen, sedangkan pertumbuhan tertinggi terjadi pada tahun 2014 sebesar 34,89 persen. Pada tahun 2015, 2016, dan 2017, tingkat pertumbuhan secara berturut-turut, yaitu 5,52 persen, 28,47 persen, dan 26,37 persen (DJPK Kemenkeu, 2019).

Dana perimbangan dan investasi yang memadai akan berdampak positif terhadap perekonomian. Modal akan tersedia apabila ada investasi, dan produksi akan meningkat dengan semakin banyaknya investor yang menanamkan modal. Pada akhirnya, produksi akan menghasilkan keluaran (output) yang tinggi dan menambah pendapatan daerah dari pajak yang akan diberikan kepada pemerintah. Pembentukan modal juga dipandang sebagai 
pengeluaran yang akan menambah kesanggupan suatu perekonomian untuk menghasilkan barang, maupun sebagai pengeluaran yang akan menambah permintaan efektif seluruh masyarakat (Pangiuk, 2017).

Tingkat pertumbuhan Penanaman Modal Dalam Negeri (PMDN) Provinsi Jambi pada tahun 2014 merupakan pertumbuhan tertinggi dalam lima tahun terakhir. Tingkat pertumbuhan PMDN terendah terjadi pada tahun 2017, yaitu $-24,37$ persen. Tingkat pertumbuhan PMDN Provinsi Jambi pada tahun 2015, 2016, dan 2018 secara berturut-turut adalah 29,19 persen, 6,79 persen, dan 9,16 persen (BPS Provinsi Jambi, 2018, 2019).

Selain PMDN, Penanaman Modal Asing (PMA) juga merupakan komponen penting yang dapat memengaruhi pertumbuhan ekonomi. Investasi asing/PMA berpengaruh secara langsung terhadap pertumbuhan ekonomi, terutama bagi negara berkembang. Kegiatan investasi ini memungkinkan suatu masyarakat untuk terus meningkatkan taraf kemakmurannya. Pengaruh yang besar ini bersumber dari tiga fungsi penting kegiatan investasi dalam sebuah perekonomian. Pertama, investasi merupakan salah satu komponen dari pengeluaran agregat. Maka kenaikan investasi akan meningkatkan permintaan agregat dan pendapatan nasional. Kedua, pertambahan barang modal sebagai akibat investasi akan menambah kapasitas produksi di masa depan dan akan menstimulasi pertambahan produksi nasional serta kesempatan kerja. Ketiga, investasi selalu diikuti oleh perkembangan teknologi (Sukirno, 2005). Seperti halnya pertumbuhan PMDN, pertumbuhan PMA selama lima tahun terakhir (2014-2018) juga mengalami fluktuasi. Tingkat pertumbuhan PMA tertinggi terjadi di tahun 2014, yaitu sebesar 17,57 persen, sementara tingkat terendah terjadi di tahun 2018 sebesar -8,3 persen. Tingkat pertumbuhan PMA pada tahun 2015, 2016, dan 2017 secara berturut-turut, yaitu 12,59 persen, -6,61 persen, dan 11,31 persen (BPS Provinsi Jambi, 2018).

Irvan dan Karmini (2016) meneliti pengaruh pendapatan asli daerah dan dana perimbangan terhadap pertumbuhan ekonomi dengan belanja modal sebagai variabel intervening di Provinsi Bali. Hasil penelitiannya menunjukkan bahwa pendapatan asli daerah dan dana perimbangan memiliki pengaruh positif dan signifikan terhadap pertumbuhan ekonomi. Sementara itu, belanja modal memiliki pengaruh negatif dan tidak signifikan terhadap pertumbuhan ekonomi kabupaten/kota di Provinsi Bali.

Chandra, dkk. (2017) dalam penelitiannya menemukan bahwa dana perimbangan secara nyata berdampak baik dan mampu memicu pertumbuhan ekonomi Provinsi Jambi. Namun, dana perimbangan juga berdampak buruk terhadap peningkatan ketimpangan antar daerah. Selanjutnya Taaha, dkk. (2010) menemukan bahwa Dana Bagi Hasil, Dana Alokasi Umum, dan Dana Alokasi Khusus berpengaruh positif dan signifikan terhadap investasi swasta di Sulawesi Tengah. Dana perimbangan tersebut dialokasikan untuk pembiayaan infrastruktur ekonomi yang akan menunjang kegiatan investasi swasta. Ketertarikan investor untuk menanamkan modal di daerah muncul karena tersedianya sarana dan prasarana yang menunjang kegiatan produksi barang dan jasa. Hal ini mengindikasikan bahwa apabila sebuah daerah ingin meningkatkan investasi swasta, maka dana perimbangan tumbuh secara positif.

Berdasarkan pembahasan di atas, penelitian ini bertujuan untuk menganalisis pengaruh dana perimbangan (dana bagi hasil, dana alokasi umum, dana alokasi khusus) dan investasi (penanaman modal asing dan penanaman modal dalam negeri) terhadap pertumbuhan ekonomi di Provinsi Jambi pada tahun 2002-2018. 


\section{Metode}

Data yang digunakan dalam penelitian ini adalah data sekunder berupa data time series tahun 2002-2018. Data bersumber dari Badan Pusat Statistik (BPS) Provinsi Jambi dan Direktorat Jenderal Perimbangan Keuangan (DJPK) Kementerian Keuangan Republik Indonesia. Untuk menganalisis pengaruh dana perimbangan dan investasi terhadap pertumbuhan ekonomi digunakan model regresi berganda dengan persamaan (1) sebagai berikut:

$$
P E=\beta_{0}+\beta_{1} \log D B H+\beta_{2} \log D A U+\beta_{3} \log D A K+\beta_{4} \log P M A+\beta_{5} \log P M D N+e t
$$

\section{Keterangan:}

$\mathrm{PE} \quad=$ Pertumbuhan Ekonomi

$\beta_{0} \quad=$ Kostanta

$\mathrm{DBH}=$ Dana Bagi Hasil

DAU = Dana Alokasi Umum

DAK = Dana Alokasi Khusus

PMA = Penanaman Modal Asing

PMDN $=$ Penanaman Modal Dalam Negeri

et $\quad=$ Variabel Pengganggu

\section{Uji Statistik}

Secara statistik, ketepatan fungsi dalam menaksir nilai aktual dapat diukur dari nilai koefisien determinasi nilai t statistik. Uji hipotesis berguna untuk memeriksa dan menguji apakah koefisien regresi yang didapat signifikan atau tidak. Nilai koefisien regresi yang secara statistik tidak sama dengan nol dianggap signifikan. Jika koefisien kemiringan (slope) sama dengan nol, maka dapat disimpulkan bahwa tidak ada cukup bukti untuk menyatakan variabel tidak bebas mempunyai pengaruh terhadap variabel bebas (Gujarati \& Porter, 2011).

\section{Uji Simultan (Uji F)}

Uji $\mathrm{F}$ dilakukan untuk mengetahui pengaruh variabel bebas $(\mathrm{X})$ secara keseluruhan terhadap variabel terikat (Y).

\section{Uji Parsial (Uji t)}

Uji t ini digunakan untuk mengetahui apakah satu variabel bebas (independen) berpengaruh secara signifikan terhadap variabel terikat (dependen). Uji hipotesis dirumuskan sebagai berikut:

$\mathrm{H}_{0}: \beta=0$ artinya variabel bebas secara individu tidak berpengaruh signifikan terhadap variabel terikat.

$\mathrm{H}_{\mathrm{a}}: \beta \neq 0$ artinya variabel bebas secara individu berpengaruh signifikan terhadap variabel terikat.

\section{Koefisien determinasi $\left(\boldsymbol{R}^{2}\right)$}

Koefisien determinasi $\left(\mathrm{R}^{2}\right)$ merupakan ukuran untuk mengetahui kesesuaian atau ketepatan hubungan antara variabel bebas dengan variabel terikat dalam suatu persamaan regresi yang dapat dilihat dari determinasi $\left(\mathrm{R}^{2}\right)$ dimana $0<\mathrm{R}^{2}<1$. Jika nilai $\mathrm{R}^{2}$ semakin dekat dengan 1 maka pengaruh variabel bebas $(\mathrm{X})$ terhadap variabel terikat $(\mathrm{Y})$ semakin kuat dan sebaliknya jika $\mathrm{R}^{2}$ semakin mendekati 0 maka pengaruh variabel bebas $(\mathrm{X})$ terhadap variabel terikat (Y). 


\section{Uji Asumsi Klasik}

Selain uji signifikansi di atas, penelitian ini juga menggunakan uji asumsi klasik. Uji asumsi klasik digunakan untuk melihat apakah variabel yang satu memiliki pengaruh terhadap variabel bebas yang lainnya. Uji asumsi klasik ini terdiri atas:

\section{Uji normalitas}

Uji normalitas adalah uji untuk melihat apakah nilai residual berdistribusi normal atau tidak. Model regresi yang baik adalah model yang memiliki nilai residual berdistribusi normal. Uji normalitas dapat dilakukan dengan uji histogram, uji normal P-Plot, uji chisquare, uji Jarque-Bera, dan uji kurtosis. Penelitian ini menggunakan uji Jarque-Bera. Untuk melihat nilai residual berdistribusi normal, nilai probabilitas harus lebih besar dari dari nilai signifikan (a) atau nilai Jarque-Bera $<$ nilai Jarque-Bera tabel.

\section{Uji multikolinearitas}

Uji multikolinearitas merupakan model regresi linear klasik yang memastikan apakah di dalam sebuah model regresi ada kolinearitas antar variabel bebas. Multikolinearitas menunjukkan adanya hubungan linear (sempurna atau tidak sempurna) di antara beberapa atau semua variabel bebas dalam model regresi. Jika terjadi multikolinearitas sempurna, maka koefisien regresi dan kesalahan standar (standard error) tidak dapat ditemukan. Jika terjadi multikolinearitas tidak sempurna, maka koefisien regresi tidak memiliki ketepatan yang tinggi serta taksiran dan kesalahan standar menjadi sangat sensitif terhadap perubahan kecil dalam data.

\section{Uji heteroskedastisitas}

Uji heteroskedastisitas digunakan untuk melihat variasi dari kesalahan pengganggu yang tidak sama untuk semua nilai variabel bebas. Ada berbagai metode yang dikembangkan untuk mendeteksi masalah heteroskedastisitas, seperti uji Park, uji Glejser, uji Korelasi Spearman, uji Goldfeld-Quandt, uji Breusch-Pagan, dan uji White. Data dianggap memenuhi asumsi heteroskedastisitas apabila nilai prob (F-statistik) lebih besar dari nilai signifikansi (a). Metode yang digunakan untuk mendeteksi masalah heteroskedastisitas dalam penelitian ini adalah dengan uji White (Mutiana, 2016).

\section{Hasil dan Pembahasan}

\section{Laju pertumbuhan ekonomi di Provinsi Jambi}

Pertumbuhan ekonomi di Provinsi Jambi mengalami perkembangan yang fluktuatif. Tingkat pertumbuhan ekonomi paling tinggi terjadi pada tahun 2011, yaitu sekitar 8,54 persen. Sedangkan tingkat paling rendah terjadi pada tahun 2015, yaitu sekitar 4,21 persen. Rendahnya pertumbuhan ekonomi disebabkan oleh lemahnya ekonomi global dan tren penurunan harga komoditas unggulan Provinsi Jambi, seperti minyak mentah, batu bara, kelapa sawit, dan karet. Struktur perekonomian di Provinsi Jambi juga masih dikuasai sektor pertanian, kehutanan dan perikanan, pertambangan dan penggalian, perdagangan besar dan eceran; reparasi dan perawatan mobil dan sepeda motor, dan industri pengolahan.

\section{Perkembangan dana bagi hasil}

Perkembangan dana bagi hasil di Provinsi Jambi pada tahun 2002-2018 mengalami pertumbuhan yang bervariasi. Pertumbuhan tertinggi terjadi pada tahun 2009, yaitu sekitar 72,46 persen, dan pertumbuhan terendah terjadi pada tahun 2007, yaitu $-39,02$ persen. Hal ini disebabkan oleh adanya perubahan nilai dan selisih dana bagi hasil akibat perbedaan hitung pemerintah pusat dengan pemerintah daerah. Perubahan atau perbedaan itu disebabkan oleh perubahan eksternal, yaitu penurunan kegiatan perekonomian, penurunan jumlah produksi 
dan harga minyak dunia, dan perubahan kurs nilai mata uang (Yusriadi dalam Mandala, 2019).

\section{Perkembangan dana alokasi umum}

Perkembangan dana alokasi umum di Provinsi Jambi pada periode 2002-2018 mengalami pertumbuhan yang dinamis. Pertumbuhan tertinggi terjadi pada tahun $2012(51,27$ persen) dan terendah pada tahun 2010 (-27,38 persen) dengan jumlah rata-rata sekitar 9,67 persen.

\section{Perkembangan dana alokasi khusus}

Perkembangan dana alokasi khusus di Provinsi Jambi dari tahun 2002 sampai 2018 memiliki rata-rata sebesar 13,51 persen. Tingkat pertumbuhan dana alokasi khusus tertinggi terjadi di tahun 2009 (43,62 persen) dan terendah di tahun 2010 (-42,97 persen).

\section{Perkembangan penanaman modal asing}

Penanaman modal asing pada periode 2002-2018 memiliki perkembangan yang fluktuatif. Tingkat pertumbuhan tertinggi terjadi pada tahun 2011 (60,57 persen) dan terendah pada tahun 2004 (-17,57 persen), serta jumlah rata-rata sekitar 15,24 persen.

\section{Perkembangan penanaman modal dalam negeri}

Penanaman modal dalam negeri di Provinsi Jambi selama tahun 2002-2018 juga mengalami perkembangan yang bervariasi. Pertumbuhan tertinggi terjadi pada tahun 2012 (115,06 persen) dan penurunan tertinggi terjadi pada tahun $2006(-51,42$ persen $)$ dari jumlah rata-rata sekitar 18,94 persen. Pertumbuhan PMDN negatif mengindikasikan bahwa penanam modal domestik enggan menginvestasikan uangnya sehingga uang yang ada lebih cenderung menjadi tabungan (Afrizal, 2015).

\section{Pengaruh dana perimbangan dan investasi terhadap pertumbuhan ekonomi}

\section{Uji simultan (Uji F)}

Uji simultan persamaan pengaruh dana perimbangan dan investasi terhadap pertumbuhan ekonomi di Provinsi Jambi diberikan pada Tabel 1. Nilai prob (F-statistik) sebesar 0,003522 yang menunjukkan bahwa Dana Bagi Hasil, Dana Alokasi Umum, Dana Alokasi Khusus, Penanaman Modal Asing, dan Penanaman Modal Dalam Negeri secara bersama-sama memiliki pengaruh signifikan terhadap pertumbuhan ekonomi pada tingkat signifikansi $(a)=1 \%$.

Tabel 1. Hasil uji simultan

\begin{tabular}{lrll}
\hline R-squared & 0.761757 & Mean dependent var & 6.107647 \\
Adjusted R-squared & 0.653464 & S.D. dependent var & 1.360356 \\
S.E. of regression & 0.800805 & Akaike info criterion & 2.664165 \\
Sum squared resid & 7.054170 & Schwarz criterion & 2.958240 \\
Log likelihood & -16.64540 & Hannan-Quinn criter. & 2.693397 \\
F-statistic & 7.034259 & Durbin-Watson stat & 1.985216 \\
Prob(F-statistic) & 0.003522 & \\
\hline
\end{tabular}

Hasil pengolahan data pada Tabel 1 menunjukkan bahwa nilai prob (F-statistik) sebesar 0,003522 berarti Dana Bagi Hasil, Dana Alokasi Umum, Dana Alokasi Khusus, Penanaman Modal Asing, dan Penanaman Modal Dalam Negeri secara bersama-sama memiliki pengaruh signifikan terhadap pertumbuhan ekonomi pada tingkat signifikansi (a) $10 \%$ atau 0,1 . 


\section{Koefisien determinasi $\left(\boldsymbol{R}^{2}\right)$}

Koefisien determinasi digunakan untuk menghitung besarnya variabel bebas (DBH, DAU, DAK, PMA, dan PMDN) terhadap variabel terikat (pertumbuhan ekonomi). Nilai koefisien determinasi $\left(\mathrm{R}^{2}\right)$ yang didapat adalah 0,761 atau 76,1 persen (Tabel 1) yang berarti bahwa pertumbuhan ekonomi di Provinsi Jambi dipengaruhi oleh Dana Bagi Hasil, Dana Alokasi Umum, Dana Alokasi Khusus, Penanaman Modal Asing, dan Penanaman Modal Dalam Negeri. Sementara itu, sisanya sebesar 23,9 persen dipengaruhi oleh variabel lain di luar model ini.

\section{Uji parsial (Uji t)}

Uji parsial atau uji t digunakan untuk mengetahui pengaruh dari masing-masing variabel bebas secara parsial terhadap variabel terikat. Tabel 2 memberikan estimasi koefisien regresi dan uji parsial (uji t) masing-masing variabel.

Berdasarkan Tabel 2 terlihat bahwa, Dana Bagi Hasil berpengaruh signifikan terhadap pertumbuhan ekonomi di Provinsi Jambi dengan nilai prob 0,0065. Dana Alokasi Umum berpengaruh signifikan terhadap pertumbuhan ekonomi dengan nilai prob 0,0384. Dana Alokasi Khusus berpengaruh signifikan terhadap pertumbuhan ekonomi dengan nilai prob 0,0758. Penanaman Modal Asing berpengaruh signifikan terhadap pertumbuhan ekonomi dengan nilai prob 0,0503. Penanaman Modal Dalam Negeri berpengaruh signifikan terhadap pertumbuhan ekonomi dengan nilai prob 0.0196 .

Tabel 2. Koefisien regresi dan uji parsial

\begin{tabular}{ccccc}
\hline & Coefficient & Std. Error & t-Statistic & Prob. \\
\hline C & 15,58887 & 23,5047 & 0,663223 & 0,5208 \\
DBH & 8,222658 & 2,452914 & 3,3522 & 0,0065 \\
DAU & $-16,51836$ & 7,02349 & $-2,351873$ & 0,0384 \\
DAK & 9,299575 & 4,744445 & 1,960097 & 0,0758 \\
PMA & 2,651935 & 1,20693 & 2,197257 & 0,0503 \\
PMDN & $-3,41904$ & 1,25288 & $-2,728945$ & 0,0196 \\
\hline
\end{tabular}

a. PE sebagai variabel terikat

Berdasarkan koefisien regresinya memperlihatkan bahwa dana bagi hasil berpengaruh positif terhadap pertumbuhan ekonomi. Dengan kata lain, peningkatan dana bagi hasil akan meningkatkan pertumbuhan ekonomi. Hasil penelitian ini sejalan dengan penelitian yang dilakukan Rahmah dan Zein (2016) di Provinsi Aceh dan Bugis (2012) di Maluku.

Dana alokasi umum meskipun menunjukkan pengaruh yang signifikan tetapi menunjukkan arah yang berlawanan (negatif) terhadap pertumbuhan ekonomi. Hal ini mengindikasikan bahwa pengalokasian dana alokasi umum kurang berkontribusi maksimal bagi pengeluaran pemerintah Provinsi Jambi sehingga tidak/kurang mampu mendorong pertumbuhan ekonomi. Hasil penelitian ini sejalan dengan penelitian Arina dkk. (2019) di Kota Manado. Namun demikian, hasil penelitian berbeda dengan temuan Endrawati dan Maryati (2010) di Sumatera Barat dan Mawarni dkk. (2013) di Provinsi Aceh yang menunjukkan adanya pengaruhi positif dana alokasi umum terhadap pertumbuhan ekonomi.

Dana alokasi khusus menunjukkan pengaruh yang positif terhadap pertumbuha ekonomi di Provinsi Jambi. Penelitian ini sejalan dengan penelitian Santosa (2013) pada 33 provinsi di Indonesia. Namun hasil ini berbeda dengan penelitian Permasari (2013) dan Dewi dan Suputra (2017) yang menunjukkan tidak adanya pengaruh dana alokasi khusus terhadap pertumbuhan ekonomi. 
Penanaman modal asing berpengaruh positif terhadap pertumbuhan ekonomi. Hasil penelitian ini sejalan dengan penelitian Rizky, dkk. (2016) pada provinsi-provinsi di Indonesia dan Afia dan Sugiyanto (2010) di Provinsi Jawa Tengah.

Penanaman modal dalam negeri meskipun berpengaruh signifikan namun dengan arah yang negatif terhadap pertumbuhan ekonomi. Hal ini menunjukkan bahwa penanaman modal dalam negeri tidak dapat berkontribusi optimal dalam jangka pendek untuk mendorong sektor-sektor riil dalam pertumbuhan ekonomi di Provinsi Jambi. Hasil penelitian ini berbeda dengan temuan penelitian Afia dan Sugiyanto (2010) dan Prasetyo (2011) yang menunjukkan adanya pengaruh positif penanaman modal dalam negeri terhadap pertumbuhan ekonomi.

\section{Kesimpulan}

\section{Kesimpulan dan Saran}

Secara simultan dana perimbangan (dana bagi hasil, dana alokasi umum, dana alokasi khusus) dan investasi (penanaman modal asing, dan penanaman modal dalam negeri) berpengaruh signifikan terhadap pertumbuhan ekonomi Provinsi Jambi. Secara parsial, dana bagi hasil, dana alokasi khusus, dan penanaman modal asing secara parsial berpengaruh positif dan signifikan terhadap pertumbuhan ekonomi, namun dana alokasi umum dan penanaman modal dalam negeri memiliki pengaruh negatif dan signifikan terhadap pertumbuhan ekonomi di Provinsi Jambi.

\section{Saran}

Pemerintah Provinsi Jambi diharapkan mampu merealisasikan Dana Bagi Hasil, Dana Alokasi Umum, dan Dana Alokasi Khusus sesuai dengan kebutuhan daerah yang memiliki pengaruh terhadap perekonomian sekarang dan di masa yang akan datang. Selain itu, Pemerintah Provinsi Jambi juga dapat mengarahkan sektor-sektor ekonomi yang efektif sehingga akan berdampak besar terhadap pertumbuhan ekonomi dan peluang kerja yang difasilitasi oleh investor asing dan dalam negeri.

\section{Daftar Pustaka}

Afia, E.N., \& Sugiyanto, F.X. (2010). Pengaruh Penanaman Modal Asing (PMA), Penanaman Modal Dalam Negeri (PMDN) dan Belanja Modal Terhadap Produk Domestik Regional Bruto (PDRB) Provinsi Jawa Tengah [Skripsi, Universitas Diponegoro]. UNDIP-IR.

Afrizal, A. (2015). Penanaman Modal Asing (PMA) serta pengaruhnya terhadap kesempatan kerja dalam perekonomian di Provinsi Jambi periode 1990-2008. Journal Development, 3(2), 18-47. http://jurnal.umjambi.ac.id/index.php/JD/article/view/60

Arina, M.M, Koleangan, R.A.M., \& Engka, D.S.M. (2019). Pengaruh Pendapatan Asli Daerah, Dana Bagi Hasil, Dana Alokasi Umum dan Dana Alokasi Khusus terhadap pertumbuhan ekonomi Kota Manado. Jurnal Pembangunan Ekonomi dan Keuangan Daerah, 20(3), 26-35. https://doi.org/10.35794/jpekd.32796.20.3.2019

BPS Provinsi Jambi. (2018). Perkembangan investasi PMA dan PMDN di Provinsi Jambi tahun 2002-2017. https://jambi.bps.go.id/dynamictable/2018/11/19/751/-investasipma-dan-pmdn-di-provinsi-jambi-2000---2017.html

BPS Provinsi Jambi. (2019). Investasi PMA dan PMDN di Provinsi Jambi tahun 2018. https://jambi.bps.go.id/dynamictable/2019/11/11/1492/investasi-pma-dan-pmdn-diprovinsi-jambi-2018.html 
Bugis, M. (2012). Pengaruh Dana Perimbangan terhadap Produk Domestik Regional Bruto (PDRB) Provinsi Maluku periode tahun 2002-2009. Maneksi Jurnal Manajemen Ekonomi \& Akuntansi , 1(1).

Chandra, D., Hidayat, S., \& Rosmeli, R. (2017). Dampak dana perimbangan terhadap pertumbuhan ekonomi dan ketimpangan antar daerah di Provinsi Jambi. Jurnal Paradigma Ekonomika, 12(2), 67-76. https://doi.org/10.22437/paradigma.v12i2.3942

Dewi, N.W.R., \& Suputra, I.D.G.D. (2017). Pengaruh Pendapatan Asli Daerah, Dana Alokasi Umum dan Dana Alokasi Khusus dan Belanja Modal terhadap Pertumbuhan Ekonomi. E-Jurnal Akuntansi Unud, 18(3), 1745-1773.

DJPK Kemenkeu. (2019). Perkembangan Dana Bagi Hasil, Dana Alokasi Umum dan Dana Alokasi Khusus. Direktorat Jenderal Perimbangan Keuangan.

Endrawati, \& Maryati, U. (2010). Pengaruh Pendapatan Asli Daerah (PAD), Dana Alokasi Umum (DAU) dan Dana Alokasi Khusus (DAK) terhadap Pertumbuhan Ekonomi: Studi kasus Sumatera Barat. Jurnal Akuntanasi \& Manajemen, 5(2).

Gujarati, D.N., \& Porter, D.C. (2011). Dasar-dasar ekonometrika. Salemba Empat.

Harefa, M. (2019). Hubungan dana bagi hasil dengan penerimaan daerah dan kemiskinan Provinsi Kalimantan Timur. Jurnal Ekonomi Dan Kebijakan Publik, 9(2). https://doi.org/10.22212/jekp.v9i2.1159

Irvan, I. P., \& Karmini, N. L. (2016). Pengaruh pendapatan asli daerah, dana perimbangan terhadap pertumbuhan ekonomi dengan belanja modal sebagai variabel intervening. E-Jurnal Ekonomi Pembangunan Universitas Udayana, 5(3), 338-362. https://ojs.unud.ac.id/index.php/eep/article/view/18193

Mawarni, M., Darwanis, D., \& Abdullah, S. (2013). Pengaruh Pendapatan Asli Daerah dan Dana Alokasi Umum terhadap Belanja Modal serta dampaknya terhadap Pertumbuhan Ekonomi Daerah (Studi pada Kabupaten dan Kota di Aceh). Jurnal Akuntansi Pascasarjana Universitas Syiah Kuala, 2(2), 80-90.

Mutiana. (2016). Analisis faktor-faktor yang mempengaruhi ekspor kopi kabupaten Tanjung Jabung Barat ke Malaysia [Skripsi, Universitas Jambi]. Perpustakaan Universitas Jambi.

Pangiuk, A. (2017). Pengaruh investasi dan pengeluaran pemerintah terhadap pertumbuhan ekonomi Provinsi Jambi (Studi tahun 2012-2015). Iltizam Journal of Shariah Economic Research, 1(1), 1-20. http://dx.doi.org/10.30631/iltizam.v1i1.90

Permanasari, W.A. (2013). Pengaruh Dana Alokasi Umum, Dana Alokasi Khusus, Pendapatan Asli Daerah dan Belanja Modal terhadap Pertumbuhan Ekonomi (Studi kasus Kabupaten/Kota di Provinsi Jawa Tengah 2009-2011). [Skripsi, Universitas Muhammadiyah Surakarta]. Universitas Muhammadiyah Surakarta.

Prasetyo, E. (2011). Analisis Pengaruh Penanaman Modal Dalam Negeri (PMDN), Penanaman Modal Asing (PMA), Tenaga Kerja, dan Ekspor terhadap Pertumbuhan Ekonomi di Jawa Tengah periode tahun 1985 - 2009. [Skripsi, Universitas Negeri Semarang]. UNNES Repository.

Rahmah, A.R., \& Zein, B. (2016). Pengaruh Pendapatan Asli Daerah, Dana Alokasi Umum dan Dana Bagi Hasil terhadap Pertumbuhan Ekonomi di Provinsi Aceh. Jurnal Ilmiah Mahasiswa Ekonomi Akuntansi (JIMEKA), 1(1), 213-220.

Rizky, R.L., Agustin, G., \& Mukhlis, I. (2016). Pengaruh Penanaman Modal Asing, Penanaman Modal Dalam Negeri dan Belanja Modal terhadap Pertumbuhan Ekonomi Provinsi di Indonesia. Jurnal Ekonomi \& Studi Pembangunan, 8(1), 9-16. 
Rofii, A. M., \& Ardyan, P. S. (2017). Analisis pengaruh inflasi, penanaman modal asing (PMA) dan tenaga kerja terhadap pertumbuhan ekonomi di Jawa Timur. Jurnal Ekonomi Dan Bisnis, 2(1), 303-316. https://doi.org/10.1234/jeb17.v2i01.1100

Santosa, B. (2013). Pengaruh Pendapatan Asli Daerah dan Dana Perimbangan Daerah terhadap Pertumbuhan, Pengangguran, dan Kemiskinan 33 provinsi di Indonesia. Jurnal Keuangan dan Bisnis. 5(2).

Sukirno, S. (2005). Ekonomi pembangunan, proses, masalah dan dasar kebijaksanaan. LPFEUI. 